\title{
Controlling of Microbial Growth by Using Cystoseira barbata Extract
}

\author{
Neveen Abdel-Raouf, Hanaa M. Mohamed*, Samah S. Mostafa ${ }^{\#}$, Ibraheem \\ B.M. Ibraheem \\ Botany and Microbiology Department and *Genetic \& Cell Biology Division, Zoology \\ Department, Faculty of Science, Beni-Suef University, Beni-Suef, 62514, Egypt.
}

\begin{abstract}
WARINE algae contain a variety of bioactive secondary metabolites and several compounds have been derived from them for prospective development of novel drugs by the pharmaceutical industries. In this laboratory experiment Cystoseira barbata was isolated from Red Sea coastal water (Safaga, Egypt). It was evaluated due to its bioactivities potential. Where the algal extract proved a potent activity against bacterial and fungal strains ranged between medium and high suppression action. It showed that Gram positive bacteria Bacillus subtilis and Staphylococcus aureus were more sensitive than Gram negative bacteria where Serratia marcescens, Pseudomonas aeuroginosa and fungus Candida albicans. Phyto-chemical analyses showed that $C$. barbata recorded the highest percentages of the flavonoids, phenols and saccharides compounds. Among the bioflavonoids determined Acacetin, Kaemp.3-(2-pcomaroyl) glucose, Rosmarinic and phenols were E-Vanillic, Benzoic and Ferulic were present in high percentages in the alga analyzed. The results indicated scope for utilizing this alga as a source of antibacterial and antifungal substances.
\end{abstract}

Keywords : Cystoseira barbata, Red Sea, Safaga, Antibacterial activity, Phyco-chemical analyses.

\section{Introduction}

Marine algae are widely distributed along the Egyptian Red Sea shore (Haroun et al., 1995; Mohamed et al., 2006 and Ibraheem et al., 2014). Among the marine flora, marine algae are rich sources of diverse bioactive compounds with various biological activities. Recently, marine algae detected as important source of novel bioactive substances. Many researchers have revealed that marine algal originated compounds exhibit various biological activities (Wijesekara, et al., 2010; Ibraheem et al., 2012 and Al-Saif, et al., 2014). During the last years, many studies have been made on biological activities of the marine algae and identified as potential sources of natural antioxidants (Matanjun et al., 2008 and AbdelRaouf et al., 2015 a \& b).

Marine organisms are sources of bioactive secondary metabolites with potent use in the development of new pharmaceutical agents (Abedin \&Taha, 2008; Abdel-Raouf et al., 2008 and EL-Gamal, 2010). Kuniyoshi et al. (1985) reported that, diphenyl ether extracted from the green alga Cladophora fascicularis was found to inhibit the growth of Escherichia coli, Bacillus subtilis and Staphylococcus aureus. Other workers found that, algal extracts from Indian water Dictyota dichotoma, and Padina gymnosora were reported to be had activity against Bacillus megatherium and $S$. aureus (Rao et al., 1981). In this respect, Pesando \& Caram (1984) reported that ethanolic extracts of Zandariania prototypus, Cystoseira sricata and Cymbula compressa inhibited the growth of different bacteria and fungi. On the national level, extracts of the Egyptian marine algae Dictyota dichotoma, Dilophus fasciola and Cystoseira barbata had antibacterial activities (El-Naggar, 1987 and Ibraheem et al., 2008). Antibacterial effects of hexane and methanol extracts of the marine algae Mastocarpus stellatus, Laminaria digitata and Ceramium rubrum on 12 marine and 7 prominent fish pathogenic bacteria were also reported (Dubber \& Harder, 2007). Methanolic extracts of 32 macro-algae from the Atlantic and Mediterranean coasts of Morocco were estimated for the production of antibacterial compounds against E. coli, S. aureus, Enterococcus faecalis and Klebsiella pneumonia (Ibtissam et al., 2009).

The current work showed the potential of $C$. barbata isolated from Red Sea, as excellent sources of novel natural products with antimicrobial activities. Since the starting materials (algal extract) was devoid of any toxicity. 


\section{Materials and Methods}

Studied area

The area investigated extends along Safaga coast on Red Sea, Egypt (Fig. 1). Safaga city located in the west coastal area of Red Sea shore between longitude $34^{\circ} 17^{\circ} \mathrm{E}$ and altitude $26^{\circ} 06^{\top} \mathrm{N}$.

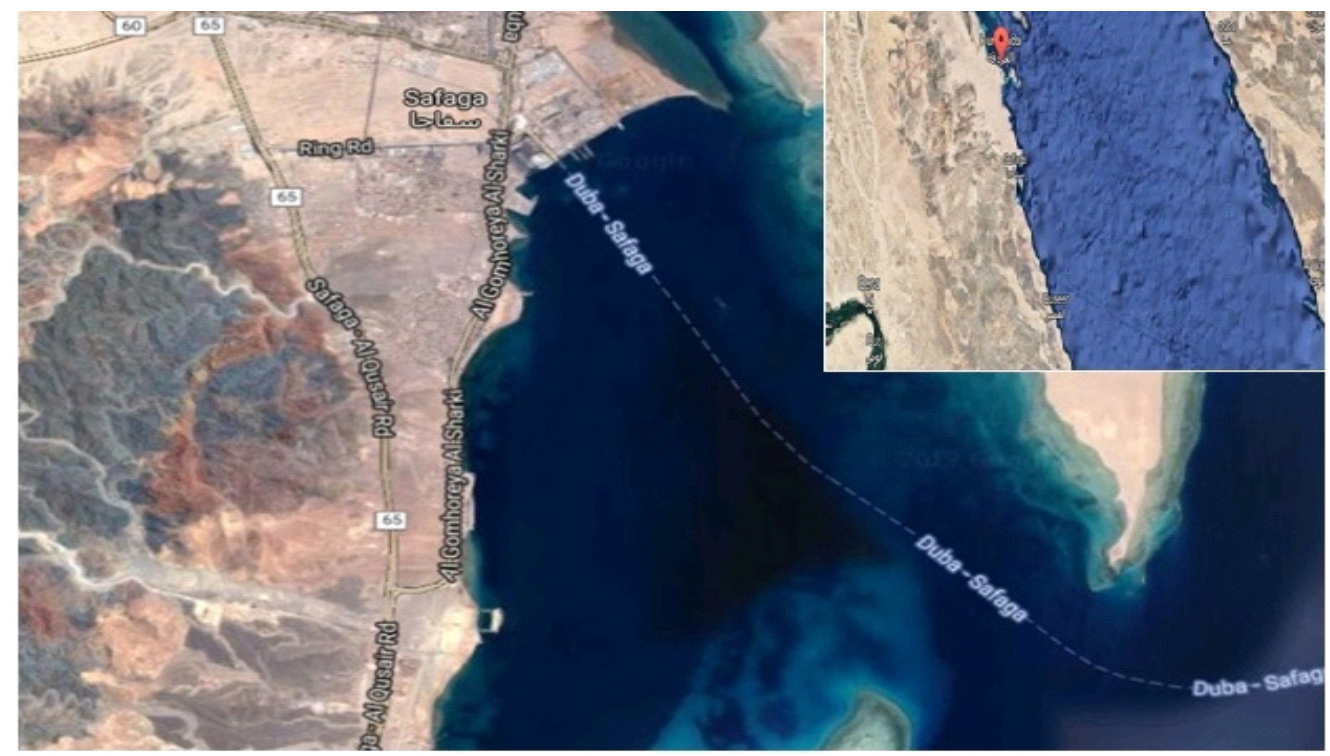

Fig. 1. Safaga location map, Rea Sea, Egypt.

Collection and identification of alga sample

Fresh and healthy marine alga $C$. barbata (Fig.2) was collected from the inter-tidal region between $(0.2-$ $2.5 \mathrm{~m}$ depths) along the Red Sea coast of Safaga, Egypt, during the period from April to June 2015. Collected sample was immediately brought to the laboratory in new plastic bags containing pond water to prevent evaporation. The algal material was washed thoroughly with tap water and distilled water to remove extraneous materials and shade-dried for 5 days and oven dried at $60^{\circ} \mathrm{C}$ until constant weight was obtained, then was grind into a fine powder using an electric mixer and stored at $0^{\circ} \mathrm{C}$ for future use. Algal species was identified (Aleem, 1993 and Coppejans et al., 2009).

Extraction for the selected algal species

Five hundred gm of Cystoseira barbata was mixed with $1000 \mathrm{ml}$ of $99 \%$ ethanol and extracted in Soxhlet apparatus for $24 \mathrm{~h}$ and after evaporation in vacuum the extracts were stored as stock algal extract at $-20^{\circ} \mathrm{C}$ until used (Krishnaveni et al., 2012).

Antimicrobial activity

Gram positive

For testing the anti-Gram positive activity, the following isolates including Bacillus subtilis (RCMB 01001 69-3), Staphylococcus aureus (RCMB 010027) and Micrococcus luteus (RCMB 01001 76-9) were selected.

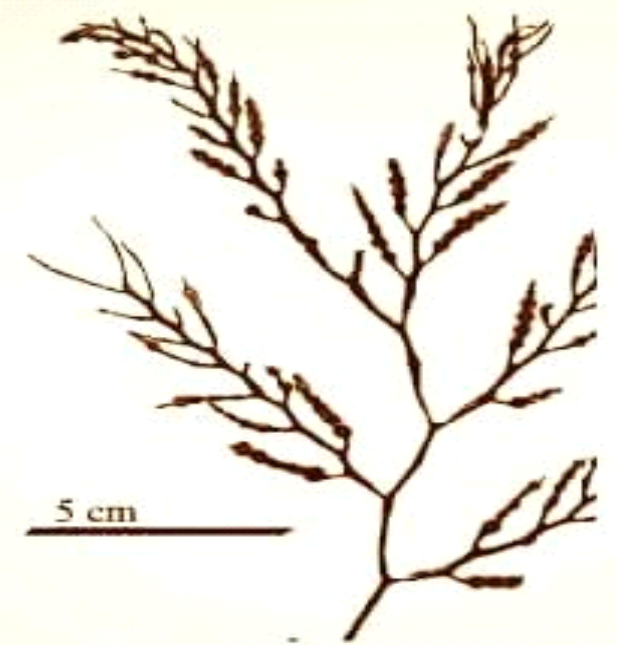

Fig. 2. Photographs of Cystoseira barbata.

\section{Gram negative}

For testing the anti-Gram negative activity, the following isolates including Escherichia coli (RCMB 01002 52-6), Pseudomonas aeruginosa (RCMB 01002 43-5), Serratia marcescens (RCMB 01002 75b-8), Salmonella typhi (RCMB 01002 15-4), Vibrio sp. and Aeromonas hydrophila were selected. 


\section{Fungi}

For antifungal activity, the unicellular Candida albicans (RCMB 05036), was used for this purpose.

Antimicrobial activity by disc diffusion method

In the present study, antibacterial activity was determined against the above bacteria using the paper disc assay method (El-Masry et al., 2000). Whatman No. 3 filter paper disc of 6-mm diameter was sterilized by autoclaving for $15 \mathrm{~min}$ at $121^{\circ} \mathrm{C}$. The sterile discs were saturated by $20 \mu \mathrm{l}$ with different concentrations $(100,200,400$ and $500 \mathrm{mg} / \mathrm{ml})$ to become loaded by 2,4,8, and $10 \mathrm{mg}$ for each disc, respectively. Agar plates were surface inoculated uniformly from the broth culture of the tested microorganisms. In all cases, the concentration was approximately $1.2 \times 10^{8} \mathrm{CFU} / \mathrm{ml}$. The impregnated discs were placed on the Muller Hinton medium suitably spaced apart and the plates were incubated at $37^{\circ} \mathrm{C}$ for $24 \mathrm{~h}$. Ethanol was used as a negative control while commercial antibiotic discs (Norfloxcin 10 $\mathrm{mg} /$ disc) were used as a positive control. The above procedure is allowed for fungal assays but expects the potato dextrose agar media instead of nutrient agar media. The plates were incubated at $25^{\circ} \mathrm{C}$ for $48 \mathrm{~h}$ in the case of investigated fungus species. The diameter of the growth inhibition halos caused by the ethanolic extract of marine organism was measured by a ruler and expressed in millimeter. All the assays were carried out in triplicate.

\section{Chemical analysis of Cystoseira barbata}

HPLC analyses of phenolic compounds, polysaccharides and flavanoids

Phenolic compounds and polysaccharides in the ethanolic extract of marine specimens were determined according to method described by Goupy et al. (1999) and Zielinski et al. (2014), respectively. The detection were conducted using high performance liquid chromatography (HPLC Agilent 1200 series) equipped with Quaternary pump, Auto sampler, column compartment set at $35^{\circ} \mathrm{C}$, multi wavelength detector set at $330 \mathrm{~nm}, 280 \mathrm{~nm}$.

\section{Statistical analysis}

All results are presented as the mean $\pm \mathrm{SD}$. Statistical analysis was carried out by using one-way ANOVA (Duncan, 1957). Statistical significance was considered at $p<0.05$.

\section{Result}

Ethanolic extract of the brown alga C. barbata was tested against some pathogenic Gram positive and Gram negative bacteria. The results of primary screening test are summarized in Table 1. C. barbata extract exhibited different antibacterial activities and inhibited all tested bacteria and fungus except Micrococcus luteus. For Gram negative bacteria, the maximum antagonistic activities of the $C$. barbata ethanolic extract $(12.16 \mathrm{~mm})$ were observed against Serratia marcescens, followed by Pseudomonas euroginosa ( $9.83 \mathrm{~mm}$, respectively) at application of $10 \mathrm{mg} /$ disc of the alga extract. On the other hand, for Gram positive bacteria, the maximum inhibition zone of the ethanolic extract of $C$. barbata was recorded against $B$. subtilis $(16.00 \mathrm{~mm})$ at application of $10 \mathrm{mg} /$ disc of the alga extract. Additionally crude extract of $C$. barbata recorded a medium antagonistic activity against fungus Candida albicans (10.33 $\mathrm{mm}$ ) at application of $10 \mathrm{mg} /$ disc of the alga extract (Fig.3).

HPLC of the C. barbata ethanolic extract (Table 2) revealed the presence of 20 flavanoids in the alga extract. Also there are three flavanoids; Acacetin, Rosmarinic and Kaemp.3-(2-p-comaroyl) glucose were recorded high level (1677.166, 462.657, 128.137 ppm, respectively). The HPLC analysis revealed also a presence of 20 phenolic compounds in the alga ethanolic extract (Table 3). Further among the different phenols maximal levels were observed with E-Vanillic (139 ppm) as compared to other phenols followed by Benzoic (128 ppm). On the other hand, the HPLC analysis revealed that, 10 saccharides were present in the alga extract, among these saccharides: glucose $(3.61 \%)$ and mannitol $(3.46 \%)$ (Table 4).

\section{Discussion}

The paper disc susceptibility test of ethanolic extract from Cystoseira barbata was shown in Table 1. Cystoseira barbata extract demonstrated a good antimicrobial activity against gram-positive strain (Bacillus subtilis and Staphylococcus aureus) and gram-negative strains (Serratia marcescens and Pseudomonas aeuroginosa) in addition to the unicellular fungus Candida albicans. It was showed that the algal extract was more effective against Gram (+) than Gram $(-)$ bacteria. The algal species belonging to genus Cystoseira possess a wide variety of compounds with different biological activities (Kolsi et al., 2015). This result disagree with Salvador et al. (2007) and Alghazeer et al. (2013) who said that $C$. barbata has no activity against $P$ seudomonas sp. The present study revealed that, ethanol is better solvent for extract the active substances of Cystoseira barbata, it was agreed with Souhaili \& Faid (2016) who reported that Cystoseira tamariscifolia would possess an active antibacterial, antifungal and antimycotoxins extractible compounds in the ethanol which must be isolated and identified for possible uses in the biotechnological and or therapeutic domain. 
TABLE 1. Antimicrobial activities of the $C$. barbata ethanolic extract (inhibition of growth expressed as mean \pm SD).

\begin{tabular}{|c|c|c|c|c|c|c|}
\hline \multirow{4}{*}{ Pathogen } & \multicolumn{6}{|c|}{ Diameter of inhibition zone, mean \pm SD } \\
\hline & \multicolumn{4}{|c|}{ Cystoseira barbata concentrations $\mathrm{mg}$ /disc } & \multirow{3}{*}{$\begin{array}{c}\begin{array}{c}\text { Norfloxcin } \\
\text { (positive) } \\
\text { control }\end{array} \\
10 \\
\text { mg/disc }\end{array}$} & \multirow{3}{*}{$\begin{array}{c}\begin{array}{c}\text { Ethanol } \\
\text { (negative) } \\
\text { control }\end{array} \\
10 \\
\mu \mathrm{l} / \mathrm{disc}\end{array}$} \\
\hline & 2 & 4 & 8 & 10 & & \\
\hline & mg/ disc & mg/ disc & mg/disc & mg/disc & & \\
\hline Micrococcus luteus & ND & ND & ND & ND & $33.30 \pm 02.88$ & 00 \\
\hline Bacillus subtilis & $11.33 \pm 0.57$ & $11.33 \pm 2.30$ & $14.00 \pm 1.00$ & $16.00 \pm 1.00$ & $26.00 \pm 04.04$ & 00 \\
\hline Gram negative bacteria & & & & & & 00 \\
\hline Serratia marcescens & ND & ND & ND & $12.16 \pm 0.57$ & $26.00 \pm 01.00$ & 00 \\
\hline Aeromonas hydrophila & $07.50 \pm 0.50$ & $08.00 \pm 1.00$ & $08.00 \pm 1.00$ & $08.00 \pm 1.00$ & $28.00 \pm 15.50$ & 00 \\
\hline Pseudomonas aeuroginosa & $06.66 \pm 0.57$ & $06.83 \pm 0.80$ & $7.66 \pm 3.78$ & $9.83 \pm 1.15$ & $33.00 \pm 02.8$ & 00 \\
\hline Escherichia coli & ND & ND & $07.33 \pm 1.15$ & $08.66 \pm 1.15$ & $11.00 \pm 01.00$ & 00 \\
\hline \multicolumn{7}{|l|}{ Fungi } \\
\hline Candida albicans & $7.60 \pm 0.57$ & $9.00 \pm 1.00$ & $10.33 \pm 0.57$ & $10.33 \pm 0.57$ & $20.00 \pm 01.15$ & 00 \\
\hline
\end{tabular}

Data are expressed as the mean \pm standard deviation (SD) of three replicates. Represent the statistical comparisons between alkaloid extract and positive control by using ANOVA $(\mathrm{p}<0.05)$. ND: not detectable
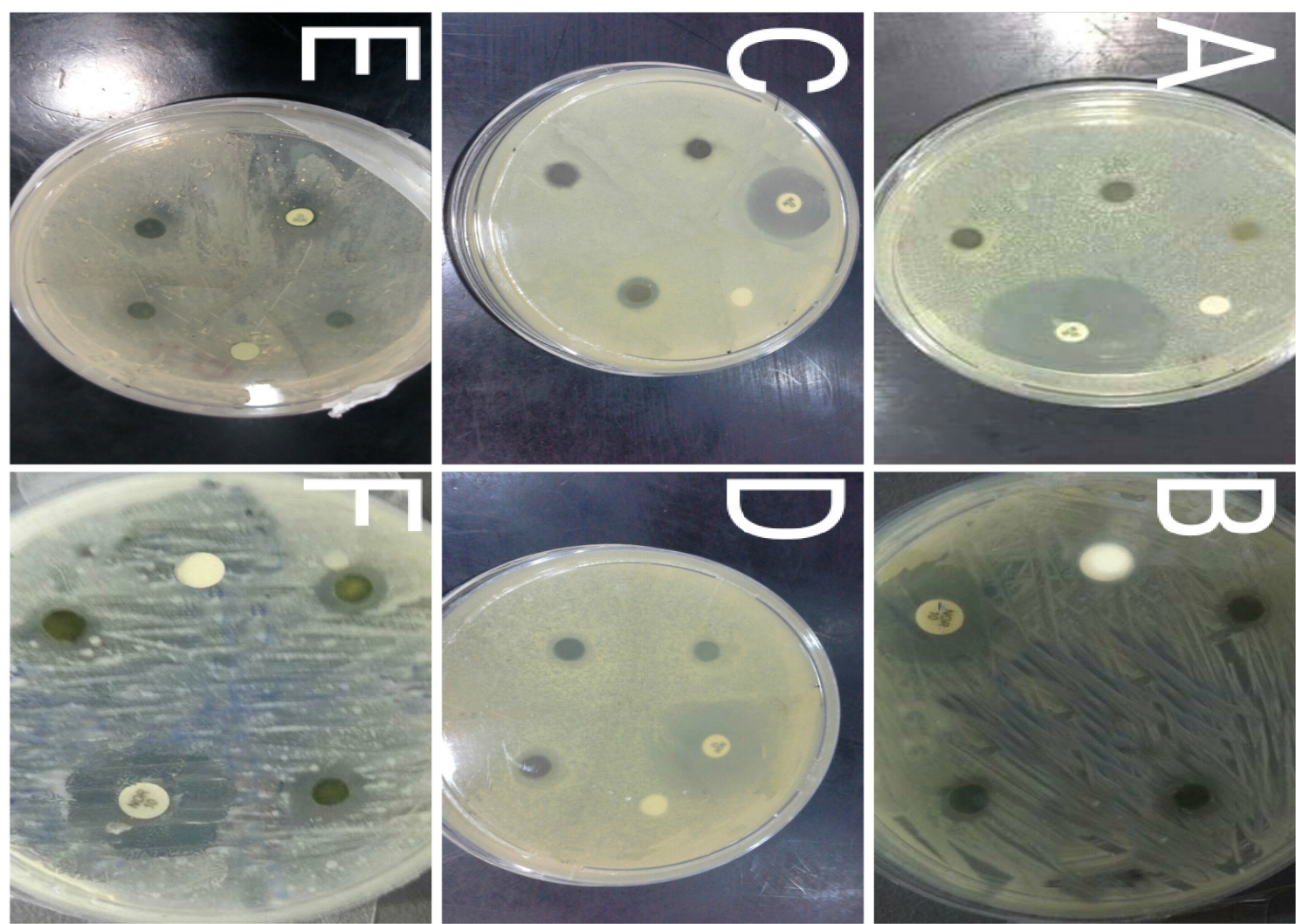

Fig. 3. Inhibition zones obtained by the ethanolic extract of Cystoseira barbata against Micrococcus luteus (A), Candida albicans (B), , Pseudomonas aeuroginosa (C), Serratia marcescens (D), Staphylococcus aureus (E) and Bacillus subtilis (F). 
TABLE 2. HPLC analysis for flavonoid contents of Cystoseira barbata isolated from Safaga Sea shore during April to June 2015.

\begin{tabular}{lc}
\hline Flavonoids contents & ppm \\
\hline Luteo.6-arabinose8-glucose & 24.904 \\
Apig.6-rhamnose8-glucose & 24.666 \\
Apig.6-glucose8-rhamnose & 10.071 \\
Naringin & 29.213 \\
Luteo.7-glucose & 9.042 \\
Hespirdin & 39.317 \\
Rutin & 9.675 \\
Quercetin-3-o-glucoside & 15.931 \\
Rosmarinic & $\mathbf{1 2 8 . 1 3 7}$ \\
Apig.7-o-neohespiroside & 7.256 \\
Kamp3,7-dirhamoside & 14.747 \\
Quercetrin & 93.287 \\
Quercitin & 6.504 \\
Kaemp.3-(2-p-comaroyl)glucose & $\mathbf{4 6 2 . 6 5 7}$ \\
Naringenin & 6.049 \\
Hespirtin & 55.784 \\
Kampferol & 35.672 \\
Rhamnetin & 20.875 \\
Apigenin & 27.085 \\
Acacetin & $\mathbf{1 6 7 7 . 1 6 6}$ \\
& \\
\hline
\end{tabular}

TABLE 3. HPLC analysis for phenolic contents of Cystoseira barbata isolated from Safaga Sea-shore during April to June 2015.

\begin{tabular}{lc}
\hline Phenolic contents & ppm \\
\hline Pyrogallol & 53.5 \\
Gallic & 7.83 \\
4-Amino-benzoic & 48.2 \\
Protocatchuic & 8.4 \\
Catechein & 59.8 \\
Catechol & 3.98 \\
Chlorogenic & 18.4 \\
Epicatechein & 8.16 \\
P-OH-benzoic & 57.7 \\
Caffeine & 17.2 \\
Caffeic & 9.1 \\
Ferulic & $\mathbf{7 1 . 6}$ \\
Iso-Ferulic & 11 \\
E-Vanillic & $\mathbf{1 3 9}$ \\
Benzoic & $\mathbf{1 2 8}$ \\
Ellagic & 46.9 \\
Coumarin & 50.1 \\
3,4,5-methoxy-cinnamic & 6.11 \\
Salycilic & 76.8 \\
Cinnamic & 8.02 \\
\hline
\end{tabular}

TABLE 4. HPLC analysis for saccharides contents of Cystoseira barbata isolated from Safaga Sea-shore during April to June 2015.

\begin{tabular}{ll}
\hline Saccharides contents & $\mathbf{\%}$ \\
\hline & \\
Glucuronic & 0.78 \\
Stachyose & 1.33 \\
Sucrose & 0.66 \\
Glucose & $\mathbf{3 . 6 1}$ \\
Xylose & 2.76 \\
Rhaminose & 0.51 \\
Mannose & 0.52 \\
Fructose & 1.62 \\
Mannitol & $\mathbf{3 . 4 6}$ \\
Sorbitol & 0.23 \\
\end{tabular}

Cox et al. (2010) reported that, organic solvents always have higher efficiency in extracting anti-bacterial compounds compared to water as extracting solvent. They said that the antimicrobial activity of red and green seaweed extracts significantly increased when ethanol and acetone were used as extraction solvents. Earlier studies have suggested that antimicrobial activity depends on the type of extraction solvent used, but also on algal species (Sunilson et al., 2009 and Boonchum et al., 2011). It is in contrast with those reported by Mhadhebi et al. (2012) who found that, antibacterial activity of methanolic extracts of some Cystoseira species revealed high antagonistic activity against tested bacteria more than petroleum ether extracts of $C$. sedoides and $C$. crinita which exhibited a moderate antibacterial activity against Escherichia coli. These results are in agreement with those reported earlier for isolating antibacterial substances as hydroquinones, sesterpenoids, phenols, brominated phenols and polyphenols from species of Chlorophyceae, Phaeophyceae and Rhodophyceae (Faulkner, 2002).

HPLC analysis of flavanoids, phenols and saccharieds for the studied alga Cystoseira barbata were carried out on extract to separate the compounds that were responsible for the inhibition tested bacteria. The inhibition activity for the ethanolic extract of Cystoseira barbata may be attributed to the presence of three flavonoid compounds, namely: acacetin, rosmarinic and Kaemp.3-(2-p-comaroyl) glucose or to the presence of the phenolic E-Vanillic or to the presence of the free saccharides glucose and mannitol which recorded high level in the alga 
extract compared to the other flavonoid, phenolic and free saccharides which present in relatively low amounts. These compounds responsible for the antimicrobial activity and assume that the active compounds could be at least partly, lipophilic halogenated compounds. Phenols have been identified in several algal species as biologically active compounds (Vairappan, et al., 2001). Many compounds of marine algae show anti-bacterial activities as polysaccharide (Laurienzo, 2010), lyengaroside (Ali et al., 2002), polyhydroxy lated fucophlorethol (Sandsdalen et al., 2003), bromophenols (Oh et al., 2008), guaiane sesquiterpene (Chakraborty \& Lipton, 2010), lactone malyngolide (Cardelina et al., 1979) cycloeudesmol (Sims et al., 1975), polyphenolic compound (Devi, 2008), halogenated compound (Vairappan, 2003) and quinone metabolite (Horie et al., 2008). Flavonoids comprise a large group of naturally compounds widely distributed in the algae and some of these compounds have been reported to contain various and potent biological activities including anti oxidative tissue protective and tumoristatic effects as well as the inhibition of hepatic cholesterol biosynthesis (Krant et al., 2005; Kim et al., 2007; Matanjun et al., 2008 and Volk, 2009). Indeed, marine algae contain polyphenols, carotenoids and flavonoids as antioxidants, protect the body's tissues against oxidative stress and associated pathologies such as cancer and inflammation (Tapiero et al., 2002).

According to the previous reports, marine algae are rich sources of fiber, minerals, proteins, antioxidant and bioactive compounds. A number of bioactive compounds which have been isolate from marine algae include sulphate polysaccharides (laminarin and fucoidans), polyphenol (such as phlorotannins), carotenoid pigments (such as fucoxantin and astaxanthin), sterols and mycosporine-like amino acids (MAAs) (Airanthi et al., 2011 and Gupta \& AbuGhannam, 2011). Bromophenol has been reported as biofuntion of antimicrobial compounds was to found in the red marine algae (Oh et al., 2008). In addition to those mentioned above, the mechanism of phenolic compounds influences the cell wall and cell membranes of microorganism. Moreover, it can interfere with the membrane function such as destroy the electron transport, nutrient uptake, protein, nucleic acid synthesis and enzyme activity. These active phenolic compounds might be several invasive targets which could lead to inhibition of bacteria (Gupta
\& Abu-Ghannam, 2011). In this study, the active compound presented in crude extracts might be interacting synergistically for bacterial inhibition.

\section{Conclusion}

In conclusion, the result of the present study confirm that marine alga Cystoseira barbata have potential source of bioactive compounds against various human pathogens, which can be used as natural non-toxic preservative and may be more acceptable to consumers. Further work is needed to identify the active compounds and role of antibacterial activity of this marine alga.

\section{References}

Abdel-Raouf, N., Ibraheem, I.B.M., Abdel-Hameed, M.S. and El-Yamany, K.N. (2008) Evaluation of antibacterial, antifungal and antiviral activities of ten marine macroalgae from Red Sea, Egypt. Egypt. J. Biotechnol. 29, 157-172.

Abdel-Raouf, N., Al-Enazi, N.M., Ibraheem, I.B.M. and Al-Harbie, R. M. (2015 a) Antibacterial and anti-hyperlipidemic activities of the brown alga Hormophysa cuneiformis from Ad Dammam Sea shore. Journal of Applied Pharmaceutical Science, 5 (08), 114-125

Abdel-Raouf, N., Al-Enazi, N.M., Al-Homaidan, A.A., Ibraheem, I.B.M., Al-Othman, M.R. and Hatamleh, A.A. (2015 b) Antibacterial $\beta$-amyrin isolated from Laurencia microcladia. Arabian Journal of Chemistry, 8( 1), 32-37.

Abedin, R.M.A. and Taha, H.M. (2008) Antibacterial and antifungal activity of cyanobacteria and green microalgae evaluation of medium components by Plackett-Burman design for antimicrobial activity of Spirulina plastensis. Global J. Biotechnol. Biochem. 3 (1), 22-31.

Aleem, A.A. (1993) "The Marine Algae of Alexandria. Egypt". Egyptian Books House.

Alghazeer, R., Whida, F., Abduelrhman, E., Gammoudi, F. and Naili, M. (2013) In vitro antibacterial activity of alkaloid extracts from green, red and brown macroalgae from western coastof Libya. Academic Journals, 12(51), 7086-7091.

Ali, M.S., Saleem, M., Yamdagni, R. and Ali, M.A. (2002) Steroid and antibacterial glycosides from marine green alga Codium iyengarii Borgesen. Natural Product Letters, 16, 407-413. 
Al-Saif, S.S., Abdel-Raouf, N., El-Wazanani, H.A. and Aref, I.A. (2014) Antibacterial substances from marine algae isolated from Jeddah coast of Red Sea, Saudi Arabia, Saudi Journal of Biological Sciences, $21,57-64$.

Airanthi, M.K.W.A., Hosokawa, M. and Miyashita, K., (2011) Comparative antioxidant activity of edible Japanese brown seaweeds. J. Food Sci. 76, 104-111.

Boonchum, W., Peerapornpisal, Y., Kanjanapothi, D., Pekkoh, J., Amornlerdpison, D., Pumas, C., Sangpaiboon, P. and Vacharapiyasophon, P. (2011) Antimicrobial and anti-inflammatory properties of various seaweeds from the gulf of Thailand. Int. J. Agric. Biol. 13, 100-104

Cardelina, I.H., Marner, E.I. and Moore, R.E. (1979) Seaweed dermatitis: structure of lyngbyatoxin. Science, 4,193-197.

Chakraborty, K. and Lipton, A.P. (2010) Guaianesesquiterpenes from seaweed Ulva fasciata and their antibacterial properties. European Journal of Medicinal Chemistry, 45, 2237-2244.

Coppejans, E., Leliaert, F., Dargent, O., Gunasekara, K. and Clerck, O. (2009) "Srilanka Seaweeds. Methodologies and Field Guide to the Dominant Species". University of Ruhuna, Dept. of Botany, Matora, Srilanka. pp.1-265.

Cox, S., Abu-Ghannam, N. and Gupta, S. (2010) An assessment of the antioxidant and antimicrobial activityof six species of edible irish seaweeds. Int. Food Res. J. 17, 205-220.

Devi, K.P., Suganthy, N., Kesika, P. and Pandian, S.K. (2008) Bioprotective properties of seaweed: In vitro evaluation of antioxidant activity and antimicrobial activity against food borne bacteria in relation to polyphenolic content. BMC Complementary and Alternative Medicine, 8, 37-48.

Dubber, D. and Harder, T.(2007) "Extracts of Ceramium rubrum, Mastocarpus stellatus and Laminaria digitata Inhibit Growth of Marine and Fish Pathogenic Bacteria at Ecologically Realistic Concentrations". Institute for chemistry and biology of the marine environment, University of Okkenburg, D-26129 Oldenburg. Germany. Aquaculture. 274, pp.196-200.

Duncan, B.D. (1957) Multiple range tests for correlated and heteroseedastic means. Biometrics, 13, 359-364.
EL Gamal, A.A. (2010) Biological importance of marine algae. Saudi Pharm. J. 18 (1), 1-33.

El-Masry, H.A., Fahmy, H.H. and Abdelwahed, A.S.H. (2000) Synthesis and Antimicrobial activity of some new benzimidazole derivatives. Molecules, 5, 1429-1438.

El-Naggar, M.E.E. (1987) Antimicrobial activity of some marine algae of Egypt. Mansoura Sci. Bull. 14 (2), 189-201.

Faulkner, D.J. (2002) Marine natural products. Nat. Prod. Rep. 19, 1-48.

Goupy, P., Hugues, M., Boivin, P. and Amiot, M.J. (1999) Antioxidant composition and activity of barley (Hordeum vulgare) and malt extracts and of isolated phenolic compounds. J. Sci. Food Agric. 79,1625-1634.

Gupta, S. and Abu-Ghannam, N. (2011) Bioactive potential and possible health effects of edible brown seaweeds, Trends in Food Science \& Technology, 22 (6), 315-326.

Haroun, B.M., Sharaf, A.M. and Ibraheem, B. (1995) Evaluation of natural productions in some common Egyptian marine algae. J. Union. Arab Biol., B, Botany, 2, 137-153

Horie, S., Tsutsumi, S., Takada, Y. and Kimura, J. (2008) Antibacterial quinone metabolite from the brown alga, Sargassum sagamianum. Bulletin of the Chemical Society of Japan, 81, 1125-1130.

Ibraheem,, B.M.I., Neveen, A.R., Mohamed, S.A.H. and Khaled, E.Y. (2012) Antimicrobial and antiviral activities against newcastle disease virus (NDV) from marine algae isolated from Qusier and Marsaalam seashore (Red Sea), Egypt. African Journal of Biotechnology, 11, 8332-8340.

Ibraheem, I.B.M., Abdel-Raouf, N., Hammouda, O. and Abdel-Wahab, N. (2008) The potential for using culture filtrate of Chroococcus minutes as fungicial agent against phytopathogenic Pythium sp. Egypt. J. Phycol. 9, 100-115.

Ibraheem, I.B.M., Alharbi, R. M., Abdel-Raouf, N. and Al-Enazi, N.M. (2014) Contributions to the study of the marine algae inhabiting Umluj Sea shore, Red Sea. Beni-Suef University Journal of Basic and Applied Sciences, 3(4), 278-285.

Ibtissam, C., Hassane, R., Jose, M., Francisco, D., 
Antonio, G., Hassan, B., Mohamed, K. and Mohamed, K. (2009) Screening of antibacterial activity in marine green and brown macroalgae from the coast of Morocco. Afr. J. Biotechnol. 8 (7), $1258-1262$.

Kim, I.H., Lee, D.G., Lee, S.H., Ha, J.M., Ha, B.J., Kim, B.J. and Lee, J.H. (2007) Antibacterial activity of Ulva lactuca against Methicillin- resistant Staphylococcus aureus (MRSH). Biotechnol. Bioprocess Eng. 12, 579-582.

Kolsi, R. Ben-abdallah, Frikha, D., Jribi, I., Hamza, A., Feki, L. and Belghith, K. (2015) Screening of antibacterial and antifongical activity in marine macroalgae and magnoliophytea from the coast of Tunisia. International Journal of Pharmacy and Pharmaceutical Sciences, 7( 3), 47-51.

Krant, K., Schlesier, K., Bitsch, R., Hermann, H., Rohe, M. and Bohm, V. (2005) Comparing antioxidative food additives and secondary plant products. Use of different assays. Food Chem. 93, 171-175.

Krishnaveni, E. Johnson, M. and Antonisamy (2012) Preliminary Phytochemical, UV-VIS, HPLC and Anti-bacterial studies on Gracilaria cirticata $J$. Ag. Asian Pacific Journal of Tropical Biomedicin: . S568-S574.

Kuniyoshi, M., Yamada, K. and Higa, T. (1985) A biologically active Diphenyl ether from the green alga Cladophora fascicularis. Experientia, 41, 523-524.

Laurienzo, P. (2010) Marine polysaccharides in pharmaceutical applications: an overview. Marine Drugs, 8, 2435-2465.

Matanjun, P., Mohamed, S., Mustapha, N.M., Mohammad, K. and Ming, C.H. (2008) Antioxidant activities and phenolics content of eight species of seaweeds from north Borneo. J. Appl. Phycol. 20(4), 367-373.

Mhadhebi, L., Chaieb, K. and Bouraoui, A. (2012) Evaluation of antimicrobial activity of organic extracts of six marine algae from Tunisian Mediterranean Coasts. Int. J. Pharm. Pharmaceutical. Sci. 4, 534-537.

Mohamed, N. A., Ibraheem, I.B. and Mohamed, S.H. (2006) Seasonal occurrence and variation in macroalgal populations in Hurghada, Safaga and Qusier Coasts of Red-Sea, Egypt. Proc. $4^{\text {th }}$ Int. Con. Biol. Sci. (Botany), pp.189-197.
Oh, K.B., Lee, J.H., Chung ,S.C., Shin, J., Shin, H.J., Kim, H.K. and Lee, H.S. (2008) Antimicrobial activities of the bromophenols from the red alga Odonthalia corymbifera and some synthetic derivatives. Bioorganic and Medicinal Chemistry Letters, 18, 104-108.

Pesando, D. and Caram, B. (1984) Screening of marine algae from the French Mediterranean Coast for antimicrobial and antifungal activity. Bot. Mar. 27, 381-386.

Rao, P.S. and Parekh, K.S. (1981) Antibacterial activity of some Indian marine algae. J. Seaweed Res. Util. 2, 82.

Salvador, N., Gómez Garreta, A., Lavelli, L. and Ribera, M.A. (2007) Antimicrobial activity of Iberian macroalgae. Sci. Mar. 71, 101-113.

Sandsdalen, E., Haug, T. and Stensvag, K. (2003) The antibacterial effect of apolyhydroxylatedfucophlorethol from the marine brown alga, Fucus vesiculosus. World Journal of Microbiology and Biotechnology, 19,777-782.

Sims, J.J., Donnell, M.S., Leary, J.V. and Lacy, G.H. (1975) Antimicrobial agents from marine algae. Antimicrobial Agents and Chemotherapy, 3, 320-321.

Souhaili1, Z. and Faid, M. (2016) Antimicrobial and antiaflatoxins activity of brown seaweed Cystoseira tamariscifolia. Basic Research Journal of Microbiology, 3(1), 01-07.

Sunilson, J.A.J., Suraj, R., Anandarajaopal, K., Rejitha, G., Vignesh, M. and Promwichit, P. (2009) Preliminary phytochemical analysis, elemental determination and antibacterial screening of Codium decorticatum-a marine green algae. Int. J. Biol. Chem. 3, 84-89.

Tapiero, H., Tew, K.D., Naguyen, G. and Mathe, G. (2002) Polyphenods: do they play a role in the prevention of human pathologies? Review. Biomed. Pharmacother. 56, 200-207.

Vairappan, C.S. (2003) Potent antibacterial activity of halogenated metabolites from Malaysian red algae, Laurencia majuscule (Rhodomelaceae Ceramiales). Biomolecular Engineering, 20, 255 259.

Vairappan, C.S., Suzuki, M., Motomuraa, T. and Ichimura, T. (2001) Pathogenic bacteria associated with lesions and thallus bleaching symptoms in the Japanese kelp Laminaria religiosa Miyabe 
(Laminariales, Phaeophyceae). Hydrobiologia, 45, 183-191

Volk, R.B. (2009) Antialgal activity of several cyanobacterial exometabolites. J. Appl. Phycol. 18, 145-151.

Wijesekara, I. and Kim, SK. (2010) Angiotensin-Iconverting enzyme (ACE) inhibitors from marine resources: Prospects in the pharmaceutical industry. Marine Drugs, 8,1080-1093.
Beltrame, F.L., Nogueira, A. and Wosiacki, G. (2014) Development and optimization of a HPLCRI method for the determination of major sugars in apple juice and evaluation of the effect of the ripening stage. Food Sci. Technol. Campinas. 34(1), 38-43.

Zielinski, A.A.F., Braga, C.M., Demiate, I.M.,

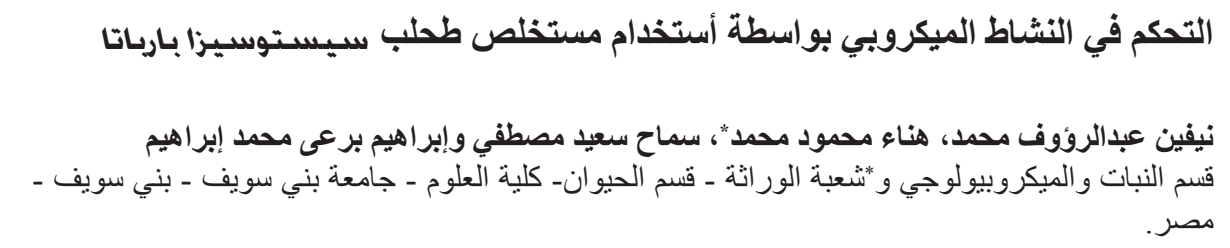

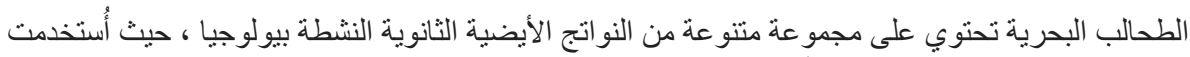

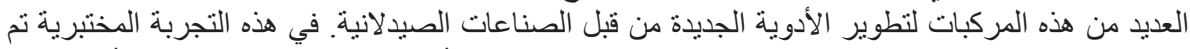

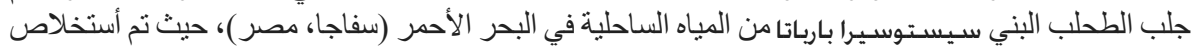

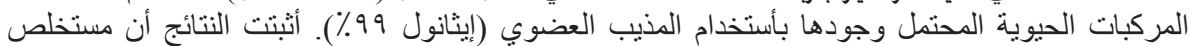

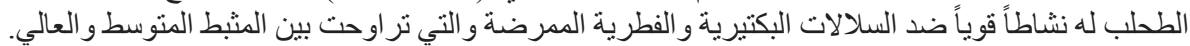

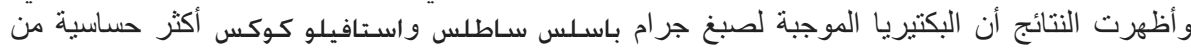

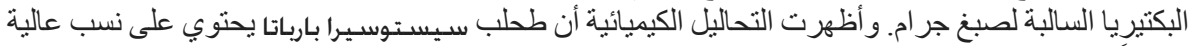

معنوياً من المركبات الفلافونويد والفينو لات والفيات السكريد ، من بينها: بيوفلافونويدز (أكاسيتين،

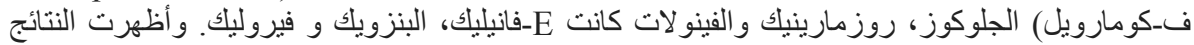

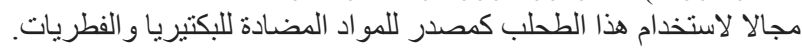

